\title{
Quality and Safety Conformance of High Rise Hospital Building Construction Practices
}

Er. Ram Bharati ${ }^{1 *}$, Er. Lalit Koju ${ }^{2}$

${ }^{1} \mathrm{Ph} . \mathrm{D}$ Scolar, University of Allahabad and Managing Director,Naya Bihani Construction Company., Koteswor-32, Kathmandu

${ }^{2}$ Powerhouse Engineer, Hydro Consult Engineering Ltd. (Mistri Khola Hydro Electric Project- MKHEP).

DOI: $10.36347 /$ sjet.2020.v08i12.002

| Received: 13.09.2020 | Accepted: 18.12.2020 | Published: 24.12.2020

*Corresponding author: Er. Ram Bharati

Abstract

Original Research Article

Good performance of any construction project refers to continuous improvement of the project activities to achieve the project objectives. This research has been designed to study the construction performances of Hospital for Advanced Medicine and Surgery (HAMS) building construction project based on quality control and safety. The quality of construction was studied by comparing the quality control test results with the standard values. The construction safety provision of HAMS project was studied through a questionnaire survey. The responses from a questionnaire survey and review of records from concerned representative were examined to identify the factor affecting the performance of building construction. The factor affecting the performance was identified and presented in various ways for the interpretation. Materials were found to be of good quality when compared with the standards, even though only $41.9 \%$ of cube moulds were of required strength as per the compressive strength results. It was due to lack of curing and poor workmanship. All the 45 labors were selected for the questionnaires for construction safety provision of the construction site. All the labors have faced minor accidents which required only first aid. Helmets, gloves, boots, safety belts and safety glasses were provided as personal protective equipment which was proper and suitable. There were no documents for the safety at site. The hygiene condition of site was good but no labors were aware about safety precautions and safety procedures at site. Nondestructive and rebar locator test for the structure were not performed though $58.1 \%$ of cube moulds were failed in their compressive strength test, so nondestructive test must be performed with expert consultation and required steps must be forwarded before operation of hospital. Effective and efficient training courses for engineers in quality, safety, productivity, information systems and management of human resources must be conducted. Consultants should be more interested about the quality of the project. Awareness programs for labors towards possible risks and hazards in a construction site can improve safety situation so awareness programs must be conducted regularly at site. The study has not covered time and cost aspects.

Keywords: Safety, Quality, Cement test, Compressive Strength, PPE, Hospital.

Copyright $($ C) 2020 The Author(s): This is an open-access article distributed under the terms of the Creative Commons Attribution 4.0 International License (CC BY-NC 4.0) which permits unrestricted use, distribution, and reproduction in any medium for non-commercial use provided the original author and source are credited.

\section{INTRODUCTION}

All the projects are planned to be completed with pre-determined quality and standard safety procedures. The relative priority is established by the client. Over the past two decades special needs pertaining to construction of high rise buildings have been established. Hospital for Advanced Medicine and Surgery (HAMS) construction project is situated at Mandikhatar, Kathmandu. It is also one of the high rises building construction project since building height is $38.15 \mathrm{~m}$. This project firstly started for apartment provision. But due to different reasons this building project is now a hospital project. The construction work was stopped for 2 years after the earthquake of 2015. The plinth area of this building is $1170.75 \mathrm{sq} \mathrm{m}$. This is a ten stories building including a helipad. If a'nonpersonal residential' structure is to be constructed, the approval from the Department of Urban Development and Building Construction (DUDBC) must be taken [1]. Nepal is a country that stands at $11^{\text {th }}$ rank in the world with respect to vulnerability to earthquake [2].

The local studies on performance improvement of hospital building constructions were not found and operation aspect of hospital has received more attention than the construction aspect [3]. So, the need of research in this field is necessary to improve the construction performance of hospital building projects in Nepal. 
More than above mentioned points it is very essential to maintain quality of work as well as safety of the labors in high rise building. The safety provision and quality management procedure must be pre planed and correctly chosen for the particular project.

\section{RESEARCH OBJECTIVE}

The present study was designed to access the building construction practices by studying the quality of material used and works done along with safety status of labors of the site of the building construction taking HAMS building construction as a case study.

\section{LITERATURE REVIEW \\ Performance Management}

In context of Nepal, there is a lack of sound project management practice. The outcome of the construction industries in Nepal are not performing well due to the lack of performance management. It was agreed that construction industry development is a deliberate process to improve the capacity and effectiveness of the construction industry in order to meet the demand for building and civil engineering products, and to support sustained national economic and social development objectives [4]. A project is a collection of activities to achieve a specific objective. Proper planning and scheduling of the project component is one of the major problem associated in Nepal for the performance affecting factor in construction industries. The main performance problem can be divided into two groups: (a) unrealistic target setting and (b) causes originating from actual construction [5]. Construction industry of Nepal based on assessment of A class contractors are not lacking in terms of Human Resource [6]. The value of the work added is found lacking in construction of Nepal shows the ineffectiveness of project management [7]. Out of several factors, quality control of materials, adequacy of design and specification, overall management practices, skillful workers and insufficient supply of materials were ranked at top based on hydropower project by Mishra and Chiluwal [8]. One of the major issues is performance of project not only at construction but also at operation as illustrated based on study conducted that of Salyankot Water Supply system [9]. After Earthquake the structure added more challenge for operation which creates more pressure to improve construction performance in Nepal [7]. Even cement handling is important for performance [10].

Cheung et al., [11] identified project performance categories such as people, cost, time, quality, safety and health, environment, client satisfaction, and communication. It is obtained by Navon [5] that a control system is an important element to identify factors affecting construction project effort. Mishra et al., [10] obtained that the most important of practices relating to scope management are controlling the quality of the contract document, quality of response to perceived variations and extent of changes to the contract.

The need for focused effort by economy managers and construction industry associations to provide the infrastructure needed for efficient project management and performance [12]. Navon [5] stated that data are collected and used for construction managers as a basis to evaluate the project performance indicators (PPI) actual value to compare it with the planned value and forecast its future value based on past performance. Shortage of skills of manpower, poor supervision, poor site management, unsuitable leadership, shortage and breakdown of equipment among others contribute to construction delays in the United Arab Emirates [13].

\section{Safety in Construction Project}

Developing a proactive safety culture may take long time and require spending of large sum of money for planning, investigating and implementing into each level within the organization. However, it is worthy of being compared with invaluable health and life of human beings. Once it succeeds, the relative rewards will be achieved in terms of competitive advantage, quality, reliability and profitability within organisation. Hinze [14] advocated the idea that safety is no luxury but a necessity. Safety culture relates to the humanitarian aspects as well as safety as an integral component. The interactive relationships between people's behavior, their attitudes and perceptions they hold, and the situation or environment in work place should be taken into account [15]. Safer behaviour is reflected by good attitude. Many accidents/incidents that occurred in the workplace especially in the building construction sites were due to inadequate adherence of workers to work procedures. The workers must realize that they play an important role contributing in the accomplishment of the building construction. The awareness and perception of the workers toward safety, health and their working environment are important aspects to enhance the building construction to the better condition to the workers themselves.

The concept of worker safety climate and how workers perceive the safety climate of their workplace was raised as an issue about 40 years ago [16]. At that time, it was recognized that successful injury control programs are based on a strong management commitment to safety, including the status of safety officers within the organization, worker training, regular communication between management and workers, general housekeeping, and a stable workforce. The term "safety culture" has many definitions according to the past researchers and they are summarized as follows:

i. Perception and beliefs, behaviour and management systems are the elements which combine to form an organization "safety culture" [15]. 
ii. "Safety culture" is the "collective behaviours of people in the organization that over time becoming patterns, typical or habit". Employees always behave in ways that the company requires them to, without considering why they need to do [17].

iii. Safety culture is an environment in which people do their tasks safely and for the right reasons [18].

Neale [19] believes that improving occupational safety and health (OSH) in the construction industry is a slow but achievable process. Thus, occupational health and safety in construction work should start at the designing table and continue throughout the construction phases until the safety and health of end users is ensured due to the complexity of the industry and the hazards it contains [20]. Ayininuola and Olalusi [21] aver that non-existent and/or lack of enforcement of construction health and safety regulations, and bylaws are among the major causes of building failures. Similarly, Asuquo et al., [22] reveals that the neglect of safety on sites may have considerable impact of worker productivity and performance and capable of undermining the reputation of construction companies thereby increasing expenses. Moreover, Akinwale and Olusanya [23] argue that awareness on possible risk factors and knowledge on how to reduce these risk factors among workers and contractors will enhance site safety. Sources of safety knowledge according to Akinwale and Olusanya [23] include incident investigation, teamwork, collaborations, and survey of safety culture. Furthermore, Mishra and Sharestha [24] argue that effective safety knowledge among construction professionals can reduce accidents that directly or indirectly reduce project cost, because in developing countries, safety rules usually do not exist, and if exist, regulatory authorities are unable to implement such rules effectively.

Mishra et al., [7] through their study concluded that safety rules and regulations not only overcome issues like poor quality work, unsafe working conditions, and lack of environmental control but also reduce cost and enhance productivity. Lama et al., [25] suggested that safety practices vary with construction sites, as every site has unique safety aspects. Larger construction projects are better organized whereas small do not have an adequate safety program or person to oversee safety criteria. It is estimated that, in China, every year, 3,000 workers belonging to construction sector were killed in work related accidents [26]. The most common cause of injuries and death in the construction sector is falling from heights [27]. The main causes include working on a scaffold or platform without guard rails, or without a safetyharness correctly attached, and fragile roofs and ladders that are badly maintained, positioned, and secured. Slips, trips, and falls are the largest cause of accidents in all sectors [28].
Management of occupational safety and health in construction has unique challenges. Despite such challenges, firms that demonstrate commitment to wellstructured and well-funded safety programmers and techniques can effectively reduce incidents [29]. Safety management techniques must often be adjusted to meet the unique needs of the industry. Because most firms allocate limited resources for safety management, contractors are forced to carefully select from the available elements [29]. Protecting labor from occupational diseases and accidents in construction industry is defined by law in developing countries. At construction sites employing 50 or more workers, the main contractor must nominate a full-time safety inspector: for sites with an area exceeding 10,000 m2, there must be two to three safety inspectors; for sites with an area exceeding 50,000 $\mathrm{m} 2$, the main contractor must establish a safety management team [30]. In Botswana, clients' attitudes and actions reveal that they consider Health and Safety as insignificant factors in considering construction projects [31]. According to Jain [32] construction safety management is a challenging task due to the dynamic nature of construction activities coupled with the involvement of an unskilled, illiterate and mobile work force in India. Permana [33] stated that workers have not been protected because safety regulations have not been thoroughly established, particularly in construction industries in Indonesia. According to Mishra et al., [7], the management commitment to the health and safety along with worker participation are essential for successful construction project. Preventive and control measures should be planned and implemented as per the risk level of hazards in Nepal.

Kamau [34] claimed that OHS regulations are just symbolic gestures and useless. OHS measures are said not to be effective in improving safety and health conditions in workplace. Workers may perceive a false level of security, when in reality there is an absence of adequate controls to prevent injuries [35]. According to Abdelhamid and Everett [36], occupational accidents occur due to one or more of the following causes:

i. Failing to identify an unsafe condition that existed before an activity was started or that developed after an activity was started;

ii. Deciding to proceed with a work activity after the worker identifies an existing unsafe condition; or

iii. Deciding to act unsafe regardless of initial conditions of the work environment.

\section{METHODOLOGY \\ Research Design}

This research identified the performance of construction of HAMS building project in terms of quality and safety. This research was designed to conduct study of the HAMS building construction project which was in operation phase (casting of fifth level) and the result obtained from the analysis of data 
helped to find the role of performance and its effect in the quality and safety of the project. The diagnostic research was used for testing of materials used for HAMS building construction followed by survey research design.

\section{Study Area}

HAMS building construction project has been constructed up to Level 4 before May 28, 2017. So construction from Level 4 onward was studied. Samples of steel, cement, sand, aggregate and cube moulds were taken for their property test. 45 labors were asked same questions related to construction safety provision of HAMS building project. The parties involved in this construction were HAMS management team as a client, Design Cell Pvt. Ltd. as the consultant, Religare Construction Pvt. Ltd. as a contractor. All the related architectural and structural drawings, rate, schedule of work etc were collected from client, consultant and contractor for the analysis.

\section{Study Population and Sample Selection}

In this study, The random selection of a cement bag from the pile of 3360 bags, one cement bag full of coarse and fine aggregate from dune and 3 numbers of $10 \mathrm{~mm}, 12 \mathrm{~mm}, 16 \mathrm{~mm}, 20 \mathrm{~mm}, 25 \mathrm{~mm}$, $32 \mathrm{~mm}$ diameter steel each for test were collected and tested. Cube molds of each casting were prepared and test of 3days, 7 days and 28 days were conducted. The tested reports were documented. 45 numbers of labors were considered for their opinion about construction safety provision of HAMS building construction project.

\section{Method of Data Collection}

Primary data were collected by field visit, lab test and interview of the personnel related to the project. Technical and other related documents were collected from Design Cell Pvt. Ltd., Religare Construction Pvt. Ltd. and HAMS management team. Questionnaires for the labors were developed for their idea about safety status of HAMS building construction site.

\section{Data Analysis}

- Cement test, fine aggregate test, coarse aggregate test, steel test and cube mold compressive test were performed for testing quality of the materials.

- Fineness test, setting time test, compressive strength test of cement was done and compared with IS 8112-1989 standard [37, 10].

- Gradation test, silt test, specific gravity test and water absorption test of fine aggregate test were done and compared with IS -383-1970 standard [38].

- Gradation test, silt test, flakiness index test, specific gravity test, water absorption test, crushing ratio test, Los Angeles Abrasion test were done for coarse aggregate and compared with IS-383-1970 standard [38].

- Tensile test of steel was done and compared with standard.

- Density and compressive strength of cube mold of 3days, 7days and 28 days as per requirement were done and compared with BS 1881-114 [39] and BS 1881-116 standards [40].

- A set of questionnaires of 36 questions related to construction safety provision of HAMS building construction project was prepared and opinion from 45 labors in site was noted. The comparative analysis was done for construction safety provision of HAMS building construction project.

\section{SUMMARY OF RESEARCH METHODOLOGY}

Table-1: Research Methodology

\begin{tabular}{|l|l|l|l|l|l|}
\hline Objectives & Indicators & $\begin{array}{l}\text { Data } \\
\text { required }\end{array}$ & Collection tools & Analysis & $\begin{array}{l}\text { Expected } \\
\text { outcomes }\end{array}$ \\
\hline $\begin{array}{l}\text { Quality } \\
\text { assessment }\end{array}$ & $\begin{array}{l}\text { Compressive test } \\
\text { Cement test } \\
\text { Aggregate test } \\
\text { Sand test } \\
\text { Steel test }\end{array}$ & $\begin{array}{l}\text { Test } \\
\text { analysis }\end{array}$ & $\begin{array}{l}\text { Pulchowk Campus and } \\
\text { Multilab Pvt. ltd }\end{array}$ & $\begin{array}{l}\text { Comparison } \\
\text { with standard }\end{array}$ & Variation \\
& $\begin{array}{l}\text { Number of accident } \\
\text { occurrence }\end{array}$ & $\begin{array}{l}\text { PPE, safety } \\
\text { plan }\end{array}$ & Questionnaires survey & $\begin{array}{l}\text { Comparative } \\
\text { analysis }\end{array}$ & Variation \\
\hline practices & & & & \\
\hline
\end{tabular}

\section{Quality control and tests}

For the quality control of materials, following tests were done.

\section{Cement test}

From the pile of cement bags, a single bag of cement was chosen as a random sample for the property test of cement 
Table-2: Test carried out and properties of cement

\begin{tabular}{|l|l|l|l|l|l|}
\hline S.N & Tests & Test status & $\begin{array}{l}\text { Observed } \\
\text { data (Tested } \\
\text { Sample) }\end{array}$ & $\begin{array}{l}\text { Specifications -43- } \\
\text { Grade-op IS 8112- } \\
\text { 1989 }\end{array}$ & Test Result \\
\cline { 4 - 6 } & Done /Not dons/Fail \\
\hline 1 & $\begin{array}{l}\text { Fineness, m2/kg: (by Blaine's Air } \\
\text { Permeability method) }\end{array}$ & Not done & & & \\
\hline 2 & $\begin{array}{l}\text { Consistency of Cement (Normal } \\
\text { consistency) }\end{array}$ & Done & $30.25 \%$ & $26 \%$ to 33\% & Pass \\
\hline 3 & Setting time & Done & & & Pass \\
\hline & Initial setting time & & 75 Min & Not less than 30 Min & \\
\hline & Final setting time & & $285 \mathrm{Min}$ & $\begin{array}{l}\text { Not more than } 600 \\
\text { Min }\end{array}$ & \\
\hline 4 & Soundness by Lechatelier method & Not done & & & \\
\hline 5 & Compressive Strength & Done & & & Pass \\
\hline & 3 Days & & $28.8 \mathrm{~N} / \mathrm{mm}^{2}$ & 23 Mpa Minimum & \\
\hline & 7 Days & & $39.50 \mathrm{~N} / \mathrm{mm}^{2}$ & 23 Mpa Minimum & \\
\hline & 28 Days & & $54.80 \mathrm{~N} / \mathrm{mm}^{2}$ & 43 Mpa Minimum & \\
\hline
\end{tabular}

Out of 5 tests only 3 tests for the cement were done. Fineness (by Blaine's Air Permeability method) and soundness test (Lechatelier method) were not available in lab so those test were not conducted. All the tested reports were within range of standard (Appendix 3). Cement quality was good based on the test reports.

\section{Steel test}

From the pile of steel rods 3 numbers of $1 \mathrm{~m}$ length of sample rods of different diameter $(32 \mathrm{~mm}$, $25 \mathrm{~mm}, 20 \mathrm{~mm}, 16 \mathrm{~mm}, 12 \mathrm{~mm}, 10 \mathrm{~mm}$ ) each were taken randomly for test.

Table-3: Test carried out and properties of steel rod

\begin{tabular}{|l|l|l|l|l|l|}
\hline S.N. & \multirow{2}{*}{ Test } & Test status & Acquired result & Limitation & Test Result \\
\cline { 5 - 6 } & & Done /Not done & & & Pass/Fail \\
\hline 1 & Tensile Test & Done & Appendix - 3 & Appendix - 3 & Pass \\
\hline 2 & Bend Test & Not done & & & \\
\hline 3 & Weld Test & Not done & & & \\
\hline 4 & Charpy V-notch Tests & Not done & & & \\
\hline
\end{tabular}

Out of 4 required tests only tensile test for the steel was done. The bend test, weld test and Charpy Vnotch tests were not available in lab so those tests were not conducted. The tested report was within range of standard (Appendix 3). The steel quality was good based on the quality test report.

\section{Fine Aggregate Test}

From sand storage about $0.1 \mathrm{cu} . \mathrm{ft}$ quantity of sand was taken from different side to make a one full bag of cement bag size for the property test of sand.

Table-4: Test carried out and properties of fine aggregate

\begin{tabular}{|c|c|c|c|c|c|}
\hline \multirow[t]{2}{*}{ S.N. } & Tests & Test status & \multirow[t]{2}{*}{ Acquired result } & \multirow[t]{2}{*}{ Limitation } & \multirow{2}{*}{$\begin{array}{l}\text { Test Result } \\
\text { Pass/Fail } \\
\end{array}$} \\
\hline & Determination of: & Done /Not done & & & \\
\hline 1 & Particle Size Distribution (Gradation) & Done & Appendix - 3 & Appendix - 3 & Pass \\
\hline 2 & Clay, Silt, Dust in Aggregates & Done & 2.16 & Max 3 & Pass \\
\hline 3 & Specific Gravity & Done & 2.644 & 2.4 to 3.0 & Pass \\
\hline 4 & Moisture Content & Not done & & & \\
\hline 5 & Bulk Density, Voids \& Bulking & Not done & & & \\
\hline 6 & Soluble Chloride Content & Not done & & & \\
\hline 7 & Mica Content & Not done & & & \\
\hline 8 & Water Absorption & Done & 1.23 & Max 3 & Pass \\
\hline 9 & Degradability Test & Not done & & & \\
\hline 10 & Sodium Sulphate Soundness & Not done & & & \\
\hline 11 & Alkali Aggregate Reactivity Test & Not done & & & \\
\hline 12 & Deleterious Substances & Not done & & & \\
\hline 13 & Sand Equivalent & Not done & & & \\
\hline
\end{tabular}


Out of 13 tests only 4 tests for the fine aggregate were done. Rest 9 tests were not available $n$ lab so those tests were not conducted. All the tested reports were within range of standard (Appendix 3). The fine aggregate quality was good based on the test reports.

\section{Coarse Aggregate Test}

From coarse aggregate storage about $0.1 \mathrm{cu} . \mathrm{ft}$ quantity of coarse aggregate was taken from different side to make a one full bag of cement bag size for the property test of coarse aggregate.

Table-5: Test carried out and properties of coarse aggregate

\begin{tabular}{|c|c|c|c|c|c|}
\hline \multirow[t]{2}{*}{ S.N. } & Tests & Test status & \multirow[t]{2}{*}{ Acquired result } & \multirow[t]{2}{*}{ Limitation } & \multirow{2}{*}{$\begin{array}{l}\text { Test Result } \\
\text { Pass/Fail }\end{array}$} \\
\hline & Determination of: & Done /Not done & & & \\
\hline 1 & Particle Size Distribution (Gradation) & Done & Appendix- 3 & Appendix- 3 & pass \\
\hline 2 & Aggregate impact value & Done & 25.97 & $\operatorname{Max} 45$ & pass \\
\hline 3 & Flakiness index & Done & 26.73 & Max 30 & pass \\
\hline 4 & Specific Gravity & Done & 2.688 & 2.4 to 3.0 & pass \\
\hline 5 & Moisture Content & Not done & & & \\
\hline 6 & Elongation Index Ratio & Done & 24.9 & Max 30 & \\
\hline 7 & Soluble Chloride Content & Not done & & & \\
\hline 8 & Mica Content & Not done & & & \\
\hline 9 & Water Absorption & Done & 0.66 & Max 3 & pass \\
\hline 10 & Crushing Ratio & Done & 24.55 & Max 30 & pass \\
\hline 11 & Los Angeles Abrasion & Done & 30.42 & Max 50 & pass \\
\hline 14 & Degradability Test & Not done & & & \\
\hline 15 & Sodium Sulphate Soundness & Not done & & & \\
\hline 16 & Alkali Aggregate Reactivity Test & Not done & & & \\
\hline 17 & Deleterious Substances & Not done & & & \\
\hline 18 & Sand Equivalent & Not done & & & \\
\hline
\end{tabular}

Out of 18 tests only 8 tests for the coarse aggregate were done and rest 10 tests were not available in lab so they were not conducted. All the tested reports were within range of standard. The coarse aggregate quality was good based on the test reports.

\section{Concrete test}

Concrete mold of each casting of PCC for RCC was prepared and it was tested in Multi Lab Pvt. Ltd in different age. Out of 7 required tests only 2 tests for the concrete were done and 5 tests were not available in lab so those tests were not conducted. All the tested reports were within the range of standard values. All the prepared cube mould had required density but only 41.9 percentage of prepared cube mould were in the range of standard in compressive strength. Although all the ingredient were of good quality the strength of cube mould were not good. Main reasons behind it were poor workmanship for preparation of cube mould and lack of curing.

Table-6: Test carried out and properties of cube mold

\begin{tabular}{|l|l|l|l|l|l|}
\hline & Tests & Test status & \multirow{2}{*}{ Test Result } \\
\cline { 2 - 3 } \cline { 5 - 6 } S.N. & Determination of: & Done /Not Done & Acquired result & \multirow{2}{*}{ Limitation } & Pass/Fail \\
\hline 1 & Air contents of fresh concrete & Not Done & & & \\
\hline 2 & Density of hardened concrete & Done & Appendix -3 & Appendix -3 & Pass \\
\hline 3 & Compressive strength of concrete cubes & Done & Appendix -3 & Appendix - 3 & 0.419 pass \\
\hline 4 & Tensile splitting strength & Not Done & & & \\
\hline 5 & Flexural strength & Not Done & & & \\
\hline 6 & Compressive strength of concrete cores & Not Done & & & \\
\hline 7 & Water absorption & Not Done & & & \\
\hline
\end{tabular}

\section{Safety Criteria}

To know the construction safety status of the construction site of HAMS building questionnaires were prepared and asked to 45 labors working in the site. The questions were divided into different aspect of safety as accidence occurrence, medical facility, documentation for safety, hygiene condition of site, working hour, individual awareness about safety, PPE provision. The individual issue related with safety results was found to be as follows: 


\section{Accidence Occurrence}

Table-7: Response for issue related to accidence occurrence

\begin{tabular}{|l|l|l|l|}
\hline Question Number & Questions & Response \\
\cline { 3 - 4 } & & Agree & Disagree \\
\hline 8 & Presence of safety representative in site & 10 & 35 \\
\hline 9 & Provision of safety meetings at site & 0 & 45 \\
\hline 10 & Provision of safety inspection at site & 10 & 35 \\
\hline 17 & Occurrence of accident at site & 45 & 0 \\
\hline 18 & Labor injured which required first aid & 45 & 0 \\
\hline 19 & Labors injured which required hospital & 0 & 45 \\
\hline 25 & Death in site due to accident & 0 & 45 \\
\hline 30 & Accident leading to disability & 0 & 45 \\
\hline
\end{tabular}

Out of 45 respondents, 35 respondents gave positive response to the safety representative and safety inspection. The entire respondent had same opinion about the safety meetings that there was no any safety meeting conducted in site. Similarly, all the respondents had seen accident in site and all the labors were injured which required the first aid. Moreover, there was no any accident occurred in site which required hospital visit or admission and they were also happy about that there were no any occurrence of death and disability of labors due to accident.

\section{Medical facilities}

Table-8: Response for issue related to medical facilities

\begin{tabular}{|l|l|l|l|}
\hline Question Numbers & Questions & \multicolumn{2}{|l|}{ Response } \\
\cline { 3 - 4 } & & Agree & Disagree \\
\hline 15 & Provision of first aid & 45 & \\
\hline 16 & Presence of medical person in site & 0 & 45 \\
\hline 28 & Provision of bearing treatment cost by contractor & 45 & \\
\hline 32 & Compensation facility after accident & 0 & 45 \\
\hline 33 & Medical examination service facility while occurrence of accident & 45 & \\
\hline
\end{tabular}

All the respondents would get first aid facilities, treatment cost if any injuries occurred and medical examination as per requirement but the respondents were dissatisfied about that there was no any medical person in site. There was first aid box in site but no one to handle it effectively. Moreover, labors were unsatisfied because they do not get any compensation if they were not able to work in site due to injury in site.
Documentation for safety site.

There were no any documents related to safety in

\section{Hygiene condition of site}

All the respondents were happy for good provision of good drinking water and toilet.

\section{Working hour}

Table-9: Response for issue related to working hour

\begin{tabular}{|l|l|l|l|}
\hline \multirow{2}{*}{ Question Numbers } & Questions & \multicolumn{2}{|l|}{ Response } \\
\cline { 3 - 4 } & & Agree & Disagree \\
\hline 1 & Working hours per day (8 hours) & 45 & 0 \\
\hline 2 & Working days per week ( 6 days) & 0 & 45 \\
\hline 3 & overtime service & 45 & 0 \\
\hline
\end{tabular}

All the labors had to work eight hours per day and they were happy since they were getting overtime services. Beside this all the labors were unsatisfied because they had to work 7 days per week. They were not getting any free time for recreation which may result dullness leading difficulties in maintaining safety within the site. 


\section{Individual awareness about safety}

Table-10: Response for issue related to individual awareness about safety

\begin{tabular}{|l|l|l|l|}
\hline Question numbers & questions & \multicolumn{2}{l|}{ Response } \\
\cline { 3 - 4 } & & Agree & Disagree \\
\hline 4 & Labors having idea about safety procedure & 3 & 42 \\
\hline 5 & Labors having idea about safety precaution & 3 & 42 \\
\hline 6 & Labors having safety trainings & 0 & 45 \\
\hline 12 & Labors able to recognize the hazard at site & 0 & 45 \\
\hline 27 & Whom to report about safety issues (supervisor) & 45 & 0 \\
\hline 36 & Labor below age 16 working in site & 45 & 0 \\
\hline
\end{tabular}

Only 3 labors had idea about the safety precautions and safety procedures at site. The entire 45 respondents were aware to report the safety issues to the supervisors. Similarly, no any respondents had got any safety trainings and they were not able to recognize all the possible hazards. Moreover, labor below the age of 16 was also working in the site which was not good in sense of safety.

\section{Personal protective equipment provision}

Table-11: Response for issue related to Personal protective equipment provision

\begin{tabular}{|l|l|l|l|}
\hline Question numbers & Questions & \multicolumn{2}{|l|}{ Response } \\
\cline { 3 - 4 } & & Agree & Disagree \\
\hline 20 & PPE provided for labors (5 out of 7) & 45 & 0 \\
\hline 21 & Suitability of PPE for labors & 45 & 0 \\
\hline 22 & Properness of PPE for safety & 45 & 0 \\
\hline
\end{tabular}

Out of 7 PPE (Helmet/ Gloves/ Boots/ Safety belts/ Masks/ Apron/ Safety glass) only 5 PPE (Helmet/ Gloves /Boots/ Safety belts/ Safety glass) were provided for the labors. According to client the contractor asked for above mentioned five PPE only and as per contractor, they can maintain their safety with those five PPE. All the respondents felt the provided PPE were proper and suitable. Due to lack of safety awareness regarding workings procedures, there seems that the labors didnot recognize the potential risks and there tend to be many smaller accidents.

Tam and Fung [16] identified that successful injury control programs are based on a strong management commitment to safety, including the status of safety officers within the organization, worker training, regular communication between management and workers, general housekeeping, and a stable workforce however, in this project no documentation for safety, no safety officers, no training for labors, no meetings related to safety. Ayininuola and Olalusi [21] claimed that non-existent and/or lack of enforcement of construction health and safety regulations, and bylaws are among the major causes of building failures. Since there were no safety regulations in construction site, this project could be call failure project in term of safety.

Sources of safety knowledge according to Akinwale and Olusanya [23] include: incident investigation, teamwork, collaborations, and survey of safety culture. This site did not have incident investigation, team work, collaborations, and survey of safety culture so nosource of safety knowledge could be gained from this site. Furthermore, Kumar and Bansal [41] argued that effective safety knowledge among construction professionals can reduce accident show ever only minor accident are experienced in this site though there were absent of safety representatives in site. Similar was the case for casual worker in road project based on a study conducted by Mishra and Sharestha [24] and Lama et al., [25] also illustrated similar situation in Project like hydropower tunneling.

So from this study it can be concluded that working condition of this site was unsafe however, hygiene condition of site was safe. It was estimated that, in China, every year, 3,000 workers belonging to construction sector were killed in work related accidents [26]. The most common cause of injuries and death in the construction sector is falling from heights [27] however, no labors death in this project were recorded and only minor accident which required first aid were observed. At construction sites employing 50 or more workers, the main contractor must nominate a full-time safety inspector [30] but no safety inspector was appointed.

Workers may perceive a false level of security, when in reality there is an absence of adequate controls to prevent injuries [42] and the same case was found in this project.

\section{CONCLUSIONS}

The qualities of materials were found to be good when test reports were compared with standards. 
- Out of 7 required tests, only 2 tests for the concrete were done. All the prepared cube moulds have required density but only 41.9 percentages of prepared cube moulds were passed in compressive strength test.

- Out of 5 tests only 3 tests for the cement were done. All the tested reports passed the standard guideline.

- Out of 4 required tests only tensile test for the steel was done. Tested steel report passed the standard guideline.

- Out of 13 tests only 4 tests for the fine aggregate were done. All the tested samples passed the standard guideline.

- Out of 18 tests only 7 tests for the coarse aggregate were done. All the tested samples passed the standard guideline.

- It has shown that the available construction materials are generally good, but the quality assurance during actual workings was very poor.

A questionnaire survey approach was conducted to study about the safety provision of this site. Safety provision of the construction was divided into different aspects as

- Accidence occurrence,

- medical facilities,

- documentation for safety,

- hygiene condition of site,

- working hour,

- individual awareness about safety and

- PPE provision.

Only the minor accidents which require first aid had occurred in the site. All the labors were satisfied for the provision of first aid in site but there was no any medical person. All the labors were provided with a medical examination service facility but no compensation facilities were provided. No safety meeting has been conducted in site for safety provisions. All the labors had to work for 8 hours per day and 7 days per week. Labors were getting overtime service. No labors had taken safety trainings and they were unable to recognize the hazards at the site. PPE, namely helmets, gloves, boots, safety belts and safety glasses were provided at the site. The entire labors responded that the provided PPE provided were proper and suitable. Labors below the age of 16 were also working in the site. There were no documents for the safety at site. All the labors were satisfied for good provision of drinking water and toilet. It can be deduced that only the presence of safety provision is not enough, but the awareness on safety procedures and safe working methods are equally important aligned with "prevention is better than cure."

\section{RECOMMENDATION}

- $\quad$ Survey from well-equipped and qualified team must be done and the required steps must be followed as per the provided report of expert team.

- It is recommended to perform the nondestructive test and rebar locator test of casted structure.

- Consultants should regularly monitor the quality of the project and the implementation of quality assurances as per required specifications.

- Contractors must carry out their works as per the specification in absence of representative of consultant.

- In addition to providing safety provisions, more important aspect is making the workers more aware towards possible risks and hazards in a construction site.

\section{ACKNOWLEDGEMENTS}

I would like to express my deepest thanks to all the helping hands without which this work would not have been completed. Specially nec CPS family and the most inspiring person Dr. Anjay Kumar Mishra who was coordinator of the M.Sc CM. We will remember his support and inspiration all the time.

\section{REFERENCES}

1. DUDBC. Kathmandu, Nepal: Department of Urban Development and Building Construction (DUDBC). 2017. Available at: dudbc.gov.np [ Accessedon June 2017]

2. Drrportal. Kathmandu, Nepal: Nepal Disaster Risk reduction portal (drrportal). 2017. Available at: drrportal.org.np [Accessed on June 2017]

3. Barakchi M. A comparative study on hospital construction cost between Norway and The United State. 2017.

4. Maskey A, Mishra AK. Labor productivity assessment of armed police force Nepal building construction projects. International Journal of Current Research 2018; 10(11).

5. Navon, R. Automated Project Performance Control of Construction Projects, Automation of Construction, 2005; 14, 467-476.

6. Mishra AK. Assessment of Human Resource Capacity of Construction Companies in Nepal. J Adv Res Jour Mass Comm. 2018; 5(4): 14-25. https://doi.org/10.24321/2454.3268.201804

7. Mishra AK, Lama C, Sah DP. Effectiveness Assessment of Preventive and Control Measures of Safety Implementation. J Adv Res Civil Envi Engr. 2019; 6(2): 1-20 Available from:https://www.researchgate.net/publication/335 464663_Effectiveness_of_Safety_Measures_Imple mented [accessed Sep 11 2020]. 
8. Chiluwal K, Mishra AK. Factors Affecting Performance of Small Hydropower Construction Projects in Nepal. Journal of Emerging Techonologies and Innovative Research. 2018; 5(6): 262-271. Available from: https://www.researchgate.net/publication/3297761 27_Assessment_of_Human_Resource_Capacity_o f_Construction_Companies_in_Nepal [accessed Sep 11 2020].

9. Mishra AK, Acharya SR. Performance Assessment of Salyankot Water Supply Project in PostEarthquake Scenario of Nepal. J Adv Res GeoSci Rem Sens 2018; 5(3\&4): 23-40 (2) (PDF) Performance Assessment of Salyankot Water Supply Project in Post-Earthquake Scenario of Nepal.

10. Mishra AK, Chaudhary U. Assessment of Cement Handling Behaviour For Selected Construction Sites of Bhatbhateni Supermarket. J Adv Res Const Urban Arch. 2018; 3(3): 1-11.

11. Cheung SO, Suen HC, Cheung KK. PPMS: a webbased construction project performance monitoring system. Automation in construction. 2004 May 1;13(3):361-76.

12. Ogunlana SO, Promkuntong K, Jearkjirm V. Construction delays in a fast-growing economy: comparing Thailand with other economies. International journal of project Management. 1996 Feb 1;14(1):37-45.

13. Faridi A, El-Sayegh S. Significant factors causing delay in the UAE construction industry, Constuction Management and Economics, 2006; 24(11), 1167-1176.

14. Hinze JW. Construction Safety. New Jersey: Prentice-Hall, Inc. 1997.

15. Dedobbeleer N, Beland F. A Safety Climate Measure for Construction Sites. Journal of Safety Research, 1991; 22, 97-103.

16. Tam CM, Fung WH. 2001. Study of Attitude Changes in People after the Implementation of a New Safety Management system: The Supervision Plan. Construction Management Economics, 2001; 19, 393-403.

17. Cooper DC. Measuring and Improving Safety Culture. Handbook for the Public Sector. New York: ESH. 1996.

18. MSA and AMI. SAFE map. Safety Culture Survey Report. Australia: Minerals Council of Australia, Australia Minerals Industry. 1999.

19. Neale R. Ten factors to improve occupational safety and health in construction projects, African Newsletter on Occupational Health and Safety, 2013; 23(3), 52-54. Available at: http://www.ttl.fi/africannewsletter.

20. Kayumba A. Editorial: Construction work and occupational safety and health. African Newsletter on Occupational Health and Safety, 2013; 23(3), 51. Available at http://www.ttl.fi/africannewsletter.
21. Ayininuola GM, Olalusi OO. Assessment of Building Failures in Nigeria: Lagos and Ibadan Case Study'. African Journal of science and technology. 2004 Jun;5(1).

22. Udo UE, Usip EE, Asuquo CF. Effect of lack of adequate attention to safety measures on construction sites in Akwa Ibom State, Nigeria. Journal of Earth Sciences and Geotechnical Engineering. 2016;6(1):113-21.

23. Akinwale AA, Olusanya OA. Implications of occupational health and safety intelligence in Nigeria. 2016.

24. Mishra AK, Sharestha M. Health and Safety Status of Casual Workers in Road Improvement Project Kathmandu Valley, Nepal. International Journal of Engineering Technology Science and Research (IJETSR) Hyperlink 2017; 4(9): 2394-3386. http://www.ijetsr.com, www.ijetsr.com Available from:

https://www.researchgate.net/publication/3354646 63_Effectiveness_of_Safety_Measures_Implement ed [accessed Sep 11 2020].

25. Lama C, Sah DP, Mishra AK. Occupational Hazards Identification and Their Risk Assessment during the Construction of Head Race Tunnel in Middle Bhotekoshi Hydroelectric Project. International Journal of Research-Granthaalayah. 2019; 7(3): 227-248.

26. Gurcanli GE, Mungen U. Analysis of construction accidents in Turkey and responsible parties. Industrial Health, 2013; 51(6), 581-595.

27. EU-OSHA. Accident Prevention in the Construction Sector: European Agency for Safety and Health at Work. 2003.

28. EU-OSHA. Innovative Solutions to Safety and Health Risks in the Construction, Health Care and HORECA Sectors, Bilbao, Spain: European Agency for Safety and Health at Work. 2011.

29. Hallowell MR, Gambatese JA. Construction safety risk mitigation. Journal of Construction Engineering and Management, 2009; 135(12), 1316-1323.

30. Tam CM, Zeng SX, Deng ZM. Identifying elements of poor construction safety management in China. Safety science. 2004 Aug 1;42(7):56986.

31. Musonda I, Smallwood J. Health and safety (H\&S) awareness and implementation in Botswana's construction industry. Journal of Engineering, Design and Technology, 2008; 6(1), 81-90.

32. Jain SK. Meeting the Challenges in Industrial Safety Management in Construction Works. 2007. Available http://www.npcil.nic.in/pdf/Endowment $\%$ 20lecture\%20by\%20CMD-1.pdf

33. Permana IE. Construction safety practices in Batam, Indonesia (a case study). MSc diss. Universiti Teknologi Malaysia. 2007.

34. Kamau EN. Enforcement and compliance on occupational health and safety measures in 
industries in Thika Municipality, Kiambu County. Bachelors Degree in Environmental Planning and Management Research Project, Department of Planning and Management, School of Environmental Studies, Kenyatta University. 2014.

35. Fleming MA. Hazard recognition techniques. By Design, 2009; 9(3), 15-18.

36. Abdelhamid T, Everett J. Identifying root causes of construction accidents. Journal of Construction Engineering and Management, 2000; 126(1), 5260 .

37. IS. Scheme Of Testing And Inspection For Certification Of 43 Grade Ordanary Portland Cement. Indian Standard (IS). 2005.
38. IS. Specification for Coarse and Fine Aggregates from Natural Sources for Concrete by Bureau of Indian Standards. 1970.

39. BS. Testing concrete. Methods for determination of density of hardened concrete. British Standard (BS). 1983.

40. BS. Testing concrete. Method for determination of compressive strength of concrete cubes. British Standard (BS). 1983

41. Kumar S, Bansal VK. Construction safety knowledge for practitioners in the construction industry. Journal of Frontiers in Construction Engineering, 2013; 2(2), 34-42.

42. Fleming K, Weltman A, Randolph M, Elson K. Piling engineering. CRC press; 2008 Sep 23. 